Petar Bojanić Institute for Philosophy and Social Theory Belgrade
UDK: 327.172 .4

Оригиналан научни рад

Примљен: 31.01. 2006.

\title{
WILL THE JUDGMENT IN THE HAGUE TRIAL CONSTITUTE A PRECEDENT IN INTERNATIONAL LAW? ${ }^{1}$
}

On the great crime (mala in se; scelus infandum) and sovereignty

In this text we are attempting to think the International Criminal Tribunal for the former Yugoslavia together, and always with its necessary connection to the International Court of Justice and International Criminal Court. By paraphrasing the title of another work, the long forgotten Hans Kelsen text from 1947 (today usually used by detractors of the Tribunal) "Will the Judgment in the Nuremberg Trial constitute a Precedent in International Law?", I wish to distinguish between the two Tribunals (as well as The Treaty of Versaille), and in so doing treat international law as legislative history or judicial precedents (and their recognition).

Key words: precedent, international law, sovereignty, responsibility, judgment.

In this text we are attempting to think the International Criminal Tribunal for the former Yugoslavia together, and always with its necessary connection to the International Court of Justice and International Criminal Court. By paraphrasing the title of another work, the long forgotten Hans Kelsen text from 1947 (today usually used by detractors of the Tribunal) "Will the Judgment in the Nuremberg Trial constitute a Precedent in International Law?"2, I wish to distinguish between the two Tribunals (as well as The Treaty of Versailles), and in so doing treat international law as legislative history or judicial precedents (and their recognition). The two words in singular in the title of my text - judgment and precedent, - should cover many different judgments and precedents which would collectively institut-

\footnotetext{
${ }^{1}$ Чланак је рађен у оквиру научноистраживачког пројекта Института за филозофију и друштвену теорију у Београду Регионални и европски аспекти интегративних процеса у Србији: иивилизацијске претпоставке, стварност и изгледи за будусност, који финансира Министарство науке и заштите животне средине Републике Србије (бр. 149031). Презентиран је 30 марта 2006 године на међународном колоквијуму "Héritage philosophique, contigence historique et universalité morale" у Паризу.

${ }^{2}$ H. Kelsen, "Will the Judgment in the Nuremberg Trial constitute a Precedent in International Law?", in The International Law Quarterly, Vol. 1, No. 2, Summer 1947, p. 153-171. This text has only been translated to Italian, in 1989. Danilo Zolo uses some of Kelsen's arguments in his criticism of the Tribunal.
} 
Petar Bojanić, Will the Judgement in the Hague Constitute a Precedent...

ionalize justice and reconciliations, in continually new ways. It seems to me that an international court achieves success only if it institutionalizes a precedent. For the court to be "successful", I assume, above all, that it puts an end to war. Only an international tribunal can definitely end war, whose main characteristics are always unprecedented atrocities.

The idiom - mala in se or scelus infandum, "evils in themselves / wrongs in themselves" or "unspeakable crime" (a crime greater than any possible crime; the term genocide can be a similar word and a possible alternative) from the subheading of this text, are used by Carl Schmitt in a "Note" ${ }^{3}$ written on August $25^{\text {th }} 1945$, in Berlin. Schmitt's sentence that "scelus infandum must by no means become a precedent", as well as his insistence that "Hitler's scelus infandum and especially the monstrous atrocities of the SS and the Gestapo cannot be classified in their real essence by the rules and the categories of the usual positive law", represent the conditions for the perpetual reconstruction of procedures and judgments of a tribunal and international law. It is precisely a crime, a monstrous and unforgivable and always unimaginable one, a crime which exceeds crime and then any adequate punishment, obligations and accountability, which introduces group, collective or state responsibility. It is at this uncertain and complicated transition between individual and collective responsibility (or shared responsibility), that I find the philosopher's task (a philosopher who supplements to the jurist, for example the "philosopher" Kelsen who adjusts the "jurist" Kelsen etc.) and the philosophical problem. This complicated transition is a philosophical problem as well as a philosophical focus ${ }^{4}$.

This is a reason why I would redirect the opening words of the title of this colloquium - "Héritage philosophique" (Philosophical heritage), in a different direction. I would not aim towards the reception of the Tribunal and the responsibility of a "philosopher" from ex-Yugoslavia to find, or not find, a space for the Tribunal's "acceptance" there, but rather, towards something else. I am interested in directing the idea of an eventual precedent by the Tribunal (the current or future ones, but necessarily the International Tribunals or International Courts) towards the word "sovereignty", which is also found in the subheading of this work. The mantra of sovereignty which has been here for the past twenty years (and continues

${ }^{3}$ C. Schmitt, "Note as Conclusion of the Opinion of prof. Dr. Carl Schmitt on 'Das international-rechtliche Verbrechen des Angriffskrieges' (August 1945)", in Das internationalrechtliche Verbrechen des Angriffskrieges; und der Grundsatz "Nullum crimen, nulla poena sine lege”, Hrsg. H. Quaritsch, Berlin, Duncker \& Humblot, 1994, S. 80-81.

${ }^{4}$ Here I repeat and follow, along with Virginia Held, the words which Annette Baier delivered in a Presidential Address before the Eighty-Seventh Annual Eastern Division Meeting of the APA in Boston December 29, 1990 in a text she titled "A Naturalist View of Persons". "(...) when we make any kind of war, we are very ready to switch from individual to collective responsibility. (...) Our philosophical focus ought to be as much on collective as on individual responsibility, when we seek to understand ourselves as persons". APA Proceedings, Vol. 65, No. 3, p. 6. Also V. Held, "Group Responsibility for Ethnic Conflict", in The Journal of Ethics, No. 6, 2002, p. 157-178. 
Социолошки преглед, vol. XXXX (2006), no. 1, стр. 93-114

today, expecting new conflicts), followed by the active participation of philosophers in it (the mantra), have led to wars and terrible crimes. The wars in Yugoslavia were carried out because of and for sovereignty. The fiction of sovereignty sovereignty that is a political emotion not a concept - led people to violence. And while the excessive desire for reality, excessive desire for sovereignty, first appeared in Serbia and its province, this does not, in any way, reduce the responsibility of the other Republics and peoples for the spread of the sovereignty and war viruses. In contrast to Nuremberg, the Tribunal at The Hague has not yet taken a negative stance towards secessionist wars and "wars in the name of sovereignty" which took the form of wars of aggression. The lack of any kind of political support, which was in Nuremberg, as Kelsen witnesses, has made The Hague process very long, procedurally flawed, and beset with difficulty in reaching a verdict. Despite the accusations that have been made against most of the leaders and military elites of the countries which participated in these conflicts, despite the ongoing search for those accused of great crimes on all sides, the sovereignty of these new states has never been questioned. Specifically, the crimes as such, through which new states were formed, have never been questioned. It is precisely at this point that a judgment by the Tribunal (a judgment that has yet to occur) could produce a precedent. In question is the impotence of erasing the older concept of sovereignty which is based on violence and force.

Twelve years after leaving the Law University in Köln, after writing numerous books about international law and peace in Geneva, Harvard, and Berkley, Hans Kelsen became the legal adviser to the United Nations War Crimes Commission in Washington, charged with the task of preparing the legal and technical aspects of the Nuremberg trial. Unsatisfied with the direction and procedures of the trial, in mid-1947 Kelsen published a text concerning the Nuremberg Trial and the problem of "precedent"s. Namely, the text was conceived as an answer to and analysis of the October 15, 1946, report to the President of the U.S. concerning the Nuremberg Trial, written by the U.S. representative to the court Chief Prosecutor Robert Jackson (Justice Jackson). Kelsen was also in a position to view his many years of thinking and writing about international law in light of the hardships faced in the trial of the German war criminals. This text is especially important for us at its end where Kelsen warns of a new, forthcoming, war and future court. Before I attempt to present the main problems of institutionalizing law into international law in the context of the International Tribunal and Court today, which Kelsen's critique presents, I would like to cite his words:

${ }^{5}$ The 1947 text, "Will the Judgment in the Nuremberg Trial constitute a Precedent in International Law?", was preceded by a noteworthy attempt by Kelsen, in 1945, to stop several problems faced by the Tribunal. "The Rule against Ex Posto Facto Laws and the Prosecution of the Axis War Criminals". The Judge Advocate Journal, 1945, No. 2, p. 8-11. 
Petar Bojanić, Will the Judgement in the Hague Constitute a Precedent...

What really impairs the authority of the judgment is that the principle of individual criminal responsibility for the violation of rules of international law prohibiting war has not been established as a general principle of law, but as a rule applicable only to vanquished States by the victors. This is specially manifest by the fact that the principle laid down in the London Agreement for the punishment of European Axis war criminals has not been inserted into the Charter of the United Nations which, although supposed to be the basis of the international law of the future, still stipulates only collective responsibility of the States as such for violations of the Charter, imputable to the responsible State, not to the acting individuals. And even more objectionable than the fact that the London Agreement has the character of a privilegium odiosum imposed upon vanquished States by the victors is that the tribunal established by the Agreement was composed exclusively of representatives of victorious States directly affected by the crimes over which this tribunal had jurisdiction. (...) One of the fundamental questions to be decided by the tribunal was the question as to whether Germany, in resorting to war against Poland and the Soviet Union, violated international treaties concluded with the States whose representatives formed the court ${ }^{6}$.

Found amongst these states, whose representatives are the judges and prosecution - continues Kelsen - is a state which had a pact with Germany and with whom this state divided Poland, as well as a state which entered into war with Japan breaking an existent non-aggression pact. Throughout the text, Kelsen attempts to defeat Robert Jackson's argument that the rules of law applied by the International Military Tribunal have been "incorporated into a judicial precedent", and he cynically concludes:

If the principles applied in the Nuremberg trial were to become a precedent $-\mathrm{a}$ legislative rather than a judicial precedent - then, after the next war, the governments of the victorious States would try the members of the governments of the vanquished States for having committed crimes determined unilaterally and with retroactive force by the former. Let us hope that there is no such precedent.

First, there is absolutely no precedent where Mr. Justice Jackson says there is one, instead it is found at a different point, where Kelsen would rather have none. To make the irony greater Kelsen himself, a few pages before the above fragment, in a certain way justified the existence of the most important precedent concerned with the principles of nullum crimen, nulla poena sine lege. Kelsen's anger that the Charter of the United Nations, which he himself was preparing, was not the most important bases for the Tribunal's verdicts opens the possibility that The Hague Tribunal might also be understood in the political context of winners and losers. However, perhaps the precedent itself (legislative, but also judicial), which all future courts must "create", is the best means by which to stop all imprecise analogies and paraphrases of Kelsen's warning from fifty years ago.

6 "Will the Judgment in the Nuremberg Trial constitute a Precedent in International Law?”, p. 170-171. 


\section{Precedent}

The problems with forming international law $^{7}$ and international tribunals ${ }^{8}$ throughout history, which Kelsen wrote about before and after Nuremberg (he wasn't the only one), show that the precedent /Präjudiz/ is a "normal" and simultaneously "essential" act as an answer to a certain problem" (that is, a crime and its different forms). The first condition for calling a judicial decision a precedent, is that it must establish a new rule of law. In that case, the use of the institution of stare decisis in every subsequent verdict is satisfied. Therefore, the precedent becomes the new law ${ }^{10}$ and is established if there is no already established law "by legislation, custom or international treaty", or if one decision fills the gap(s) in the law. There are countless reasons as to why numerous new precedents have been established in international law. In much smaller processes than the ones we mention here, the precedent was a "means" by which judicial efficacy was reached. Two interesting examples could lead us to a limited precedent which particularly interests Kelsen. This is a precedent which does not relate only to the future and all subsequent decisions of similar cases, but rather a precedent which acts retroactively, meaning backwards and before. A precedent whose force lies in the fact that it opens new cases in the past and enables the punishment for those acts which, when they occurred, were not "covered" by law,

7 "In the interests of peace it is better to speak of international right than - as only too often happens - to hold forth about a nebulous justice, and then to neglect the development of an international law which is still in its infancy. (...) The present state of international law is characterized by the fact that international common law - considered from a technical standpoint - is still in the stage of a primitive system of law, that is to say, it is at a stage from which the legal system of the individual States originally developed. This is a condition of extensive decentralisations". H. Kelsen, The Legal Process and International Order, London, Constable \& Co., 1935, p. 11, 14.

8 "But experience teaches that states submit more easily to an international court than to an international government". H. Kelsen, Law and Peace in International Relations, Cambridge, Harvard University Press, 1942, p. 169.

9 "Precedents are what they are because men faced with a problem and ask 'Have we not had this before or something like it?"'. This sentence, uttered by Lord Wright, is found in Mohamed Shahabuddeen's book Precedent in the World Court (Cambridge University Press, 1996, p. 6). Shahabuddeen was a long time judge on the International Court of Justice (19881997) and is a present day ICTY judge. "'Precedent' is usually taken to mean any prior decision possible relevant to the present case to be decided (...) it is not necessary that the deciding court expressly adopts or formulates a decision to guide future decision-making in order to talk about it as a precedent. Being relevant for any future decision is sufficient”. R. Alexy, R. Dreier, "Precedent in the Federal Republic of Germany", in Interpreting Precedents: A Comparative Study. Ed. D. N. MacCormick, Aldershot, Darmouth, Ashgate, 1997, p. 17-64.

${ }^{10}$ Kelsen especially insists on the law-creating function of precedents and that a precedent must have binding force. "Will the Judgment in the Nuremberg Trial constitute a Precedent in International Law?", p. 154, 162. 
Petar Bojanić, Will the Judgement in the Hague Constitute a Precedent...

and were therefore not processed. Therefore, it is not true that only justice can be late, law can be late as well. This lateness can be annulled thanks to, or luckily because of, the precedent. All this could be very important, and in some cases the extreme injustice of some laws (we'll immediately speak of them).

The two examples I mentioned earlier are quite well known: in the case of Regina v. Imre Finta in Canada, a trial for "crimes against humanity" was carried out on the basis of a 1987 Canadian statute which permits retrospective application of international law. In its judgment the Court recognized the existence of "crimes against humanity" under international law before 1945; the Eichmann precedent illustrates the possibility of a State that did not exist at the time of the crime (Israel) trying to punish a foreign citizen for genocide, when it has a legitimate and fundamental link to the victims. Despite being determined to prove that the judgment in the Nuremberg Trail does not constitute any kind of precedent in international law, Kelsen nonetheless allows for the international agreement concluded on August 8, 1945, in London, for the Prosecution of European Axis War Criminals, by the Governments of Great Britain, the United States of America, France, and the Soviet Union, to be true precedents ${ }^{11}$. The argumentation he uses is interesting and overlaps with the critique of positivism (Kelsen's) which at that time Gustav Radbruch was using in his two analyses of injustice and crimes against humanity ${ }^{12}$. Kelsen says that the law which was applied in the judgments at Nuremberg was ex post facto law. Specifically, the London Agreement "provides individual punishment for acts which, at the time they were performed were not punishable, either under international or under any national law. The rule against retroactive legislation has certainly not been respected by the London agreement"13. However, despite the illegality of this law it, continues Kelsen, "seems also to be an exception to the rule against ex post facto laws".

Justice required the punishment of these men, in spite of the fact that under positive law they were not punishable at the time they performed the acts made punishable with retroactive force. In case two postulates of justice are in conflict with each

11 "Will the Judgment in the Nuremberg Trial constitute a Precedent in International Law?", p. 154, 155, 162. In this way the London Agreement are made more significant, but only under the condition that some of its amendments are necessarily incorporated into the Charter (p. 170).

${ }^{12}$ Radbruch publishes two texts immediately following Nuremberg in Süddeutsche Juristen-Zeitung : "Gesetzliches Unrecht und übergesetzliches Recht" (1946, No. 1, S. 105-108) and "Zur Diskussion über die Verbrechen gegen die Menschlichkeit" (1947, No. 2, S. 131-135).

${ }^{13}$ In the first chapter of the August 1945 text "Die praktische Bedeutung des Satzes: 'Nullum crimen, nulla poena sine lege", Carl Schmitt cites articles 7 I 8 of the so called "Erklärung der Menschen- und Bürgerrechte": 7. Nul home ne peut être accusé ni détenu que dans les cas déterminés par la loi, et selon les formes qu'elle a prescrites. 8. (...) et nul ne peut être puni qu'en vertu d'une loi établie et promulguée antérieurement au délit et légalement appliquée. Das international-rechtliche Verbrechen des Angriffskrieges; und der Grundsatz "Nullum crimen, nulla poena sine lege", Hrsg. H. Quaritsch, Berlin, Duncker \& Humblot, 1994, S. 19. 
Социолошки преглед, vol. XXXX (2006), no. 1, стр. 93-114

other, the higher one prevails; and to punish those who were morally responsible for the international crime of the Second World War may certainly be considered as more important than to comply with the rather relative rule against ex post facto laws, open to so many exceptions ${ }^{14}$.

Does the "size" of the crime, or a crime found a posteriori, or defeat in a war dictate this exception and right to a precedent?

This great confusion and typical objection are certainly easily overcome by the establishing of several additional measures and procedural conditions for the systematic application of a precedent. For example, Schmitt's insistence in differentiating mala prohibita and mala in $s e^{15}$ (or singular, malum in se) could be useful, but only under the conditions that the size of a great crime is not idealized and that the size of a small crime is not belittled, and further, that the jurisdiction of a tribunal, which could only possibly render a verdict differentiating the two, not be idealized, because it supposedly cannot punish malum in $s e^{16}$. It is not enough to remove the existence of this difference with standard positivistic arguments about morality which is not part of law, about the principle nonexistence of mala in se, about delict is not outside of law, about law as such being intrinsically good etc. Non acceptance of this difference has created a mutated and transformed grammatical difference between mala-malum (number, the difference between plural and singular). When the Republic of Serbia's team disputes the International Court of Justice's jurisdiction in the case concerning the Application of the Convention on the Prevention and Punishment of the Crime of Genocide (Bosnia and Herzegovina v. Serbia and Montenegro), besides the argument that there was no intention to destroy a part of, groups, peoples (the number is already found in the text of article 2 ), it continuously speaks of the number of victims and inhabitants before and after aggressions. The number of those killed is not enough ("... had been estimated 4 to 12 victims of willful killing and a limited number of victims of inhuman treatment, totaling in all less than 20 persons"), says Luis Moreno-Ocampo, Chief Prosecutor

14 "Will the Judgment in the Nuremberg Trial constitute a Precedent in International Law?", p. 164, 165.

15 “(...) mala in se, or wrong in themselves and those that are mala prohibita and wrong merely because they are punished by statute". A text with no name and author entitled "The Distinction Between Mala Prohibita and Mala in se in Criminal Law", Columbia Law Review, Vol. 30, 1930, p. 74-86. For Schmitt piracy is a "malum in se" in the absolute sense, while being a pirate means to be the enemy of all of humanity lein Feind der ganzen Menschheit/ and waging war against humanity /gegen die Menschheit geführter Krieg/. Das internationalrechtliche Verbrechen des Angriffskrieges, S. 50-54.

${ }^{16}$ For Schmitt malum in se is committing a so called world crime /Weltverbrechen/ but no international criminal court has, as of yet, been found for it. C. Schmitt, "Völkerrecht. Ein juristisches Repetitorium, 1948/50", in Frieden oder Pazifismus?, Arbeiten zum Völkerrecht und mit Anmerkungen versehen von G. Maschke, Berlin, Duncker \& Humblot, 2005, S. 766, 823. 
Petar Bojanić, Will the Judgement in the Hague Constitute a Precedent...

of the International Criminal Court, for the initiation of an investigation by the ICC.

(...) because the Statute requires consideration of admissibility before the Court, in light of the gravity of the crimes. Bearing in mind that a key consideration in this regard is the number of victims of particularly serious crimes, he concluded that the situation did not appear to meet the "gravity" threshold".

The number of the living will certainly be a decisive factor in the referendums for independence of Montenegro or Kosovo, perhaps the latter one occurring even as soon as the end of this year. Violence of insufficient number and violence of excessive number seems to springs from the perversion of this difference between crimes and the refusal to accept this difference in some form. To avoid Schmitt's theology, Kaufmann's or Lauterpacht's natural law, Kelsen's positivism in international law etc., and to actualize law through justice, it is first of all - by means of the institution of precedent - necessary to revise the unconditionality of norms in public law. If there is a total contradiction (Radbruch calls it "intolerable") between positive law and justice, which cannot be reduced, if the law is incorrect /unrichiges Recht/ and surpasses the level of tolerance (which can be accepted), then it is necessary to give justice the privilege (lex iniusta non est lex).

One limit line /Grenzziehung/, can be drawn with most precision: where there is not even an attempt to achieve justice /wo Gerechtigkeit nicht einmal erstrebt wird/, where equality, the core of justice /Kern der Gerechtigkeit/, is deliberately disavowed in the enactment of positive law, the law is not merely "incorrect law" /unrichtiges Recht/, it lacks entirely the very nature of law /Rechtsnatur/. For law, including positive law, cannot be otherwise defined than as an order and legislation whose very meaning is to serve justice ${ }^{18}$.

Because it is impossible to immediately remove certain laws which sow extreme injustice, in the Nazi era for example, where positive law loses its legal quality or its legal validity ${ }^{19}$, it must be done afterwards. In this way an unbreak-

${ }^{17}$ Letter from February 9th 2006. See The International Criminal Court and the 2003 invasion of Iraq.

18 G. Radbruch, "Gesetzliches Unrecht und übergesetzliches Recht", Süddeutsche Juristen-Zeitung, 1946, No. 1, S. 107. This text is copied in G. Radbruch, Rechtsphilosophie, Stuttgart, K. F. Köhler Verlag, 1973, S. 345-346. Also R. Alexy, „A Defence of Radbruch's Formula", in Recrafting the Rule of Law: The Limits of Legal Order, Ed. D. Dyzenhaus, Oxford, Hart, 1999, S. 16., and F. Handelman, "G. Radbruch vs. H. Kelsen: A debate on Nazi Law", in Ratio Juris, Vol. 18, No. 2, June 2005, p. 162-178.

${ }^{19}$ In an interview, broadcast on the $6^{\text {th }}$ of February 1972, on Südwestfunk radio in Baden Baden, Schmitt maliciously asks what the declared positivist Kelsen would do in Schmitt‘s place during Nazism, alluding to the fact that he (Schmitt) is not a positivist and that he did not attempt to "follow" and "use" the Reich's laws. He then recalls a conversation from 1926 between the Viennese Professor Hold von Ferneck and Kelsen. Ferneck asks his positivist colleague "If there is a case of a lunatic lawmaker who decides to kill ten people by firing squad each week, its not important for what reason, for example because they have red hair, should we 
Социолошки преглед, vol. XXXX (2006), no. 1, стр. 93-114

able connection would be made between the force of one law to represent a preventive measure (danger from injustice is recognized in advance) and the retroactive force of one eventual law which stands above every law as such (justice can be reached in reverse by invalidating the injustice of the existing law).

A precedent absolutely establishes relativism in law only if its use is completely restricted and if certain "structures" and "functions," which are usually concerned with the sovereign or sovereignty, are protected and immunized. For example, the establishing of a precedent and the retroactive punishment of all those who committed different crimes, while "covered" by laws they themselves passed, should also encompass the dissolution of the very sovereignty based on which they legally controlled a certain territory and held executive power. All that is problematic in the history of imagining the International Tribunal or the International Court, from Kant to Kelsen, is found precisely at the point at which responsibility for crimes stops before the walls of sovereignty. Namely, a tribunal or court is the perfect opportunity for the responsibility for crimes to truly overcome the confines of the right to sovereignty or the rights of a people to self-determination or the right to self-constitution. What does this mean? That a tribunal or court, through precedent, can forever undermine the sovereignty of a state whose citizens participated in crimes, and in this way undermined the sovereignty of states as the subject of international law in general. Undermining does not mean a temporary withdrawal and appropriation of a state's sovereignty in the form of punishment coming from another state (that is, all other states) "possessing" it and giving it back to the "mutilated" state. Rather undermining represents a systematic demystification of sovereignty and sovereign violence (power, souveräne Gewalt ${ }^{20}$ ) founded on crime, and a diminished significance of force and violence in the constituting and preser-

then treat that as justice and law?" Kelsen answered without hesitation: "I am a jurist, not a moralist". Eclectica, Over en in zake Carl Schmitt, Hrsg. P. Tommissen, 1975, S. 105. This interview was recently translated to Italian, in the book C. Schmitt, Un giurista davanti a se stesso, a cura di G.Agamben, Vicenza, Neri Pozza, 2005, p. 41-66.

${ }^{20}$ Kant mentions sovereign authority (violence, but power as well) in paragraph 54 of the book The Metaphysics of Morals. "(...) A league of nations /Völkerbund/ in accordance with the idea of an original social contract is necessary, not in order to meddle in one another's internal dissensions /nicht in die einheimischen Misshelligkeiten derselben zu mischen/ but to protect /zu schützen/against attacks from without/gegen Angriffe der äusseren Feinde/. This alliance must, however, involve no sovereign authority (as in a civil constitution), but only an association /sondern nur eine Genossenschaft/ (federation); it must be an alliance that can be renounced at any time and so must be renewed from time to time leine Verbündung, die zu aller Zeit aufgekündigt werden kann, mithin von Zeit zu Zeit erneuert werden muß/”. I. Kant, Practical Philosophy, Cambridge University Press, 1996, p. 482-483. Die Metaphysik der Sitten, GS, Band VI, S. 344. In another text I worked on the unclear sentence "against attacks from without" (both Natorp and Vorländer have differing opinions of the meaning of this sentence as one word is missing from Kant's work). It seems that it's possible, in the context of Kant's many lectures, to show that Kant allowed in international law interference "in another's internal dissensions" (sovereignty) and that he defended the right to preventive war. 
Petar Bojanić, Will the Judgement in the Hague Constitute a Precedent...

ving of rights (justice, the system etc. ${ }^{21}$. The states represented in this tribunal, by daring to "interfere" in the sovereignty of a state or states - whose regimes waged wars in which crimes were committed - admit their own responsibility and share a kind of common 'sovereign responsibility' before the crimes committed. War is above all the defeat of the whole community as well as the defeat of its construction founded on sovereignty. The tribunal or court represents the ad hoc acceptance of this defeat.

\section{Precedent and Responsibility}

The true precedent of the London Agreements from August 1945, on which Kelsen insists and which as such should immediately be incorporated into the Charter of the United Nations, is concerned with responsibility. Here, again, is the fragment we already cited:

What really impairs the authority of the judgment is that the principle of individual criminal responsibility for the violation of rules of international law prohibiting war has not been established as a general principle of law, but as a rule applicable only to vanquished States by the victors. This is specially manifest by the fact that the principle laid down in the London Agreement for the punishment of European Axis war criminals has not been inserted into the Charter of the United Nations which, although supposed to be the basis of the international law of the future, still stipulates only collective responsibility of the States as such for violations of the Charter, imputable to the responsible State, not to the acting individuals.

The next war, the next court, and the future trouble Kelsen, because the winner does not apply these principles of individual criminal responsibility to himself, nor is he responsible as the State. For Kelsen the problematic interpretations of several documents, on which a military tribunal bases its legality, also open the horizon of a new war, and consequently a new court. If we recognize the Tribunals and Courts in The Hague as Kelsen's next imaginary court which follows real war (wars) - taking into account that the "legal and judicial history" of courts does not exist yet, and the fact that every ensuing international tribunal either used or neglected the experiences of the previous tribunals in a totally uncontrolled manner - it seems that the basic document "in the international law of the future" (today that "future" should be in The Hague) is not "Kelsen's" Charter (The Charter of the United Nations) but rather "Mr. Justice Jackson's" charter. Jackson, in the October 15, 1946 Report to the President, says that the agreements concluded in London, in which individual criminal responsibility is central, are "a

${ }^{21}$ This should be a completely contrary direction from Kelsen, as well as Kant. The main problem with international law and the absence of peace and security is, for Kelsen, the lack of a monopoly and coercive force, and because of that a total lack of decentralization. There is an important fragment concerning violence (force) and rights (“(...) without might no right can be instituted...”) In Kant's Lectures on Ethics from 1793 (Cambridge University Press, 1997, p. 279 et seq.; $G S$, Band XXVII, S. 515 et seq.). 
Социолошки преглед, vol. XXXX (2006), no. 1, стр. 93-114

basic charter in the international law" ${ }^{\prime 22}$. Many deliberate misinterpretation of the Agreement were made, in order to give it advantage over the Charter, as well as the loss of all the legacies left by the processes carried out after The First World War. By systematically circumventing international law, in the favor of a precedent of individual criminal responsibility, the governments which acceded to the London Agreement "did not consider themselves obliged or authorized by existing International Law to prosecute organs of the guilty State as criminally responsible for its delict" ${ }^{23}$. Why? And furthermore, why is the emphasis, after sixty years, again on individual responsibility? Is it even possible to expect that this emphasis will be annulled, after almost thirteen years of the ICTY's existence, by means of some sort of sudden precedent (this could be a pleonasm) or sudden agreement, which could reassign collective responsibility? Is it necessary to bring back the possibility of judgment in absentia? Is it possible to judge a deceased leader of a state thus saving the lengthy work of compiling evidence in the name of other processes? Is it possible to make a precedent and give a photograph, film, recorded telephone conversation etc. the status of evidence? Is it possible to revise "governmentalities" of independent republics once when the judgment processes are finished and the main actors have been punished for their crimes? Is it necessary to reevaluate the idea of aggressive war and introduce criminal delict's against peace? Is a judgment pertaining to the responsibility of a state for genocide all that is left for us to expect?

Most of these questions bring us back to the beginning, to what Kelsen thought of for years, and to what is again becoming active in Hague, more specifically in the International Court of Justice: can a state be guilty and criminally responsible? ${ }^{24}$ But this is also Kant's question or perhaps a much older one, the question addressed by Moses to God: the number; how many?; maybe two?; a family, a tribe, a mob, a group, a people; how many of them can be mobilized around evil?; Can a crime be committed collectively? Can this "collective" be held

22 "Will the Judgment in the Nuremberg Trial constitute a Precedent in International Law?", p. 168.

${ }^{23}$ H. Kelsen, "Collective and Individual Responsibility for Acts of State in International Law", in The Jewish Yearbook of International Law, Jerusalem, Rubin Mass, 1949, p. 239.

${ }^{24}$ On March $7^{\text {th }} 2006$, Alain Pellet (CR /11, p. 26-42), in the name of the team from Bosnia and Herzegovina, spoke and listed the specific remedies available in the standard sources on State responsibility: compensations, restitution, satisfaction, cessation and assurances and guarantees of non-repetition.

"In order to refute the prevailing doctrine societas delinquere non potest (a corporation cannot commit a crime) and to prove that States can incur criminal responsibility, it is not necessary to make the hopeless attempt to demonstrate that the State as a juristic person is not a legal fiction but a real being, a super-individual organism, and the like. The decisive question is not whether the State is a legal fiction or a real thing but whether the sanctions which are to be directed against the State as such, that is, war and reprisals, can be interpreted as "punishment". Such an interpretation is certainly possible". H. Kelsen, Peace through Law, University of North Carolina Press, 1944, p. 73. 
Petar Bojanić, Will the Judgement in the Hague Constitute a Precedent...

responsible and punished for these crimes? Who can even decide collectively and is collective responsibility a consequence of the forced "personification" and "integrity" of a political community? ? $^{25}$

Here are two examples which, each in their own way forced Moses and Kant to think "collective" responsibility through the prism of a precedent.

1. The Lord was in the position of judging of Korah (Korahite), the first leftist in the history of humanity, and his two hundred and fifty Israelites' (chieftains of the community) who rebelled against Moses and Aaron. Before the Lord definitely chooses Moses, and before he commits one of the most horrific acts of violence ever seen (this is the famous example, used by Walter Benjamin, of pure divine violence, violence without blood and violence which does not produce right) - as the earth will open and swallow all of them, their families, and all their possessions, as if they never existed - the Lord insists and attempts several times to physically separate the two sides so there is no collateral damage ("Stand back from this community that I may annihilate them in an instant!") ${ }^{26}$. The difficulty in finding this borderline between the right group and the wrong one is made more demanding by Moses' opposition and begging: "O God, Source of the breath of all flesh! When one man sins, will You be wrathful with whole community? ${ }^{27 "}$ This is a very good example of how insisting and calling for individual responsibility supposes a sovereign community and the protecting of the winner. Moses' hypocritique /hypo-crisis/ and resistance before the Lord's decision/crisis/, occurred while the majority, headed by Moses himself, already did not participate in sharing responsibility.

2. The always important second paragraph in Kant's book Metaphysics of Morals, begins with a state (in the singular form) whose rights against an unjust

${ }^{25}$ In the text "How can Individualists share Responsibility?" (Political Theory, Vol. 21, No. 2, May 1993, p. 228-248), Annette Baier connects these two Dworkian concepts with several of Kant examples of the death penalty and the sharing of responsibility from Lectures on Ethics and Metaphysics of Morals.

${ }^{26} \mathrm{Kant}$, in this magnificent example of an attempt to share responsibility, emphasizes precisely that which confirms the sovereignty of a community and limits responsibility. He finds two conditions which are key for constituting the concept of an Ethical Commonwealth: first is the assumption of the existence of a super moral being /eines höhern moralischen Wesens/, i.e. the idea of God, which enables Kant to call the community of people which manage to come out (of the state of nature) "People of God," and the existence of another idea which contrasts the first one and the community: that is "the idea of a rabble of the evil principle" /die Idee einer Rotte des bösen Princips/. "To such a people of God we can oppose the idea of a rabble of the evil principle, the union of those who side with it for the propagation of evil, and whose interest it is to prevent the realization of that other union - although here again the principle which combats virtuous dispositions lies in our very selves and is represented only figuratively as an external power". I. Kant, Religion within the Limits of Reason alone, New York, Harper, 1934, p. 91; GS, Band VI, S. 100.

${ }^{27}$ The JPS Torah Commentary, Numbers Bamidbar, tr. J. Milgrom, Philadelphia New York, Jewish Publication Society, 1990/5750, p. 135. Numbers 16, 21-22. 
enemy /ungerechte Feind/ have no limits ("no limits with respect to quantity or degree, however there are limits with respect to quality"). An unjust enemy represents a state (Kant will eventually, at the end of the fragment, say that it is a $\operatorname{state}^{28}$ ) which deserves to be eliminated or whose government deserves to be eliminated. Within the fragment, Kant makes several stipulations as to what sort of treatment an unjust enemy deserves. He attempts to limit the punishment that all other states exact upon this state which is not an enemy, which is below the level of enemy. Such an enemy is unjust because its status as subject or state is completely uncertain. This is perhaps a "country" which is in a state of nature, a tyrannical country, a rogue country etc. But before all of this, it is a state which threatens neighboring states by arming and it is a state which violates public contracts.

Since this can be assumed to be a matter of concern to all nations whose freedom is threatened by it, they are called upon to unite against such misconduct /sich gegen einen solchen Unfug zu vereinigen/ in order to deprive the state of its power to do it. But they are not called upon to divide its territory among themselves /um sich in sein Land zu teilen/ and to make the state, as it were, disappear from the earth, since that would be injustice against its people /denn das wäre Ungerechtigkeit gegen das Volk/, which cannot lose its original right /sein ursprüngliches Recht/ to unite itself into a commonwealth /ein gemeines Wesen/, though it can be made to adopt a new constitution that by its nature will be unfavorable to the inclination of war $^{29}$.

These famous "standards of sovereignty" ("unjust enemy", "injustice against people", "original right) have been unreservedly repeated for more than two hundred years. They are brought into question not only through historical context (from epoch to epoch they remain unchanged) with perpetually similar wars, enemies, and crimes. Even for The Hague, even failure in The Hague, which Kant mentions in paragraph sixty one (Kant's book was published in 1797), today can represent a cruel analogy ${ }^{30}$. So, while all the peoples (nations) were "called", in the

\footnotetext{
${ }^{28}$ Both Vattel and Achenwall, from whom Kant takes this idiom, are much more hesitant to call this enemy a state.

${ }^{29}$ I. Kant, Practical Philosophy, Cambridge University Press, 1996, p. 487. Die Metaphysik der Sitten, GS, Band VI, S. 349. This paragraph is complemented with a very interesting fragment from Kant's lectures on natural law, from 1784 (from Feyerabend's notes). In the context of jus praeventionis Kant analyzes occupatio bellica with all his institutions, such as restitution, "Die Quantitas der Satisfactio", indemnitas etc. GS, Band XXVII, S. 1372, 1373 et seq.

30 "Such an association of several states to preserves peace can be called a permanent congress of states, which each neighbouring state is at liberty to join. Something of this kind took place (at least as regards the formalities of the right of nations for the sake of keeping the peace) in the first half of the present century, in the assembly of the States General at the Hague. The ministers of most of the courts of Europe and even of the smallest republics lodged with it their complaints about attacks being made on one of them by another. In this way they thought of the whole of Europe as a single confederated state which they accepted as arbiter, so to speak, in their public disputes. But later, instead of this, the right of nations survived only in books; it disappeared from cabinets or else, after force had already been used, was relegated in the form of a deduction to the obscurity of archives". Ibid, p. 487-488; S. 350.
} 
Petar Bojanić, Will the Judgement in the Hague Constitute a Precedent...

end there were only "several"; and only two states, Russia and Prussia, which deprived the power of the enemy, the unjust enemy of the day being Poland; its territory was completely divided and annexed (Kant stays quiet about all this). In viewing the new Polish constitution, adopted on May $3^{\text {rd }} 1791$, Kant is completely skeptical. He believed nothing that come from Poland was trustworthy because that state had no middle class, nor culture ${ }^{31}$. In Kant's opinion "having culture" or "being at a certain cultural stage," necessarily leads to war. In this way the circle is definitely closed, because "the highest stage of culture is the state of war of the peoples in equilibrium..." / die höchste Stufe der Cultur ist der Kriegszustand der Völker im Gleichgewicht.../2. Those who should "give" or "allow" the people to "adopt a new constitution that by its nature will be unfavorable to the inclination of war" /sondern es eine neue Verfassung annehmen zu lassen, die, ihrer Natur nach, der Neigung zum Kriege ungüstig ist/, themselves do not posses such a constitution. Kant's (and not only Kant's) suggestion truly sounds attractive and "loving": instead of dividing and destroying this harmful state, all nations or a group of states are supposed to give these people what they themselves do not posses ("their original right to unite" ostensibly making them innocent and not responsible for what their government has done). Otherwise, they are allowed the impossible: to alone find that which no one possesses yet.

More than one hundred and fifty years later, in the middle of a horrible war and before the Trials at Nuremberg, the so-called "Four-Power Declaration" was adopted at the historic Moscow conference. Here again a "loving" moment occurs, as the Declaration concludes that it is necessary to quickly establish a general international organization "based on the principle of the sovereign equality of all peace-loving States, and open to membership by all such States, large and small, for the maintenance of international peace and security"33. It would be truly unacceptable and false to be satisfied with certain hypocritical passages in these famous examples as they contain crimes and extreme violence within their foundations. Crimes "organize" or "initiate" the crisis of sovereignty because an end to the war which produces them (these crimes) is expected. It is at the moment at which a court puts an end to a war that the sovereignty of all of its actors also

${ }^{31}$ Kant, in his Lectures in Anthropology from the winter semester of 1784/85 (from Mrongovius' notes), says that freedom is necessary for the passing of a civil constitution, followed by laws or restrictions on the freedoms of an individual, so that he would not infringe upon the freedom on another (individual) and force/violence/Gewalt/, for the law to be set. Poland and Turkey are negative examples. Turkey being an example of despotism, while Poland has too much freedom, none respects the laws and a harmonious whole cannot be established. I. Kant, GS, Band XXV (2), S. 1424.

${ }^{32}$ I. Kant, GS, Band VII, Anthropologie in pragmatischer Hinsicht. 2. Nachdr. D. Ausg. 1917, S. 411.

${ }^{33}$ The Conference was held in October 1943 with the participation of the Governments of United States of America, the United Kingdom, the Soviet Union and China. The quote is taken from H. Kelsen's text "The Principle of Sovereign Equality of States as a Basis for International Organization“", in The Yale Law Journal, Vol. 53, March, 1944, No. 2, p. 207. 
comes to an end. There is no war: there is no sovereignty, but only during the court's tenure. It is the court that principally oppresses sovereignty and necessarily makes everyone responsible. Only if the court were to exist perpetually is Kelsen's threatening horizon of a future war, and consequently a future court, prevented.

Here are several possible conditions and precedents which are, today, at the disposal of the International Tribunal and which create a balance between individual criminal responsibility, a state which is guilty and criminally responsible, and the responsibility of all:

1. The principle of collective responsibility is constructed on the idea that the one who committed a delict is not the only one responsible, but that others are as well. First, because every individual belongs to a certain community (the smallest possible legal community ${ }^{34}$ ) and an ad hoc international community or state of all, and second, because it is impossible and unjust that one individual, as a part or organ of a community, answers alone for the crimes (mala in se, scelus infandum) he committed. ${ }^{35}$

2. An international court legalizes sanctions already imposed on a community in the form of reprisals and war. ${ }^{36}$ In this way the court should use what the 1928 Kellogg-Briand Pact stipulates: all states are part of one joint convention ${ }^{37}$ and are all authorized (not only the immediate victim of a possible armed attack) to resort to war against a state which in violation of this convention has undertaken an armed attack. Every armed attack belongs to the "war of aggression" family and is illegal. The only legal armed action is an action of all against one lerga omnes, "action contre un Etat fautif" ${ }^{38}$

${ }^{34}$ H. Kelsen, Law and Peace in International Relations, Harvard University Press, 1942, p. 98; "Collective and Individual Responsibility in International Law with Particular Regard to the Punishment of War Criminals, in California Law Review, Vol. 31, 1942-43, p. 532, 534.

${ }^{35}$ In an indictment, signed by the prosecutor Richard J. Goldston on February 13th 1995, one convict from The Hague is charged with 140 of the gravest criminal offences.

${ }^{36}$ See I. Brownlie, "The Concepts of just war and just reprisals", in State Responsibility, Part I, Oxford, Clarendon Press, 1983, p. 3-4.

${ }^{37}$ Kelsen analyzes one version of Article 11 the League of Nations (after the March 11th resolution was adopted ) in the book Legal Technique in International Law, A Textual Critique of the League Covenant, in Geneva Studies, Vol. X, No. 6, December 1939, p. 82 I et seq. "Any war or threat of war, whether immediately affecting any of the Members of the League or not, is hereby declared a matter of concern to the whole League, and the League take any action..."

${ }^{38}$ The Kellogg-Briand Pact replaced the classic, and always problematic, distinction between just and unjust wars with a new distinction between legal and illegal wars. But, only this agreement again opens the possibility for a definite return to a radical doctrine concerning the forbiddance of war (hors la loi or "outlawry of the war"). E. Kaufmann, Règles générale du droit de la paix, in Recueil des cours, Paris, Sirey, 1935, Tome 54, p. 597, 599, 602, 603. Kelsen's text "E possibile e desiderabile definire l'aggressione ?" (Scritti di diritto internazionale in onore di Tomaso Perassi, Vol. II, Milano, Giuffre, 1957, p. 3-19), is the final, in a series of texts which expound on the impossibility to define aggression and Kelsen's attempt to justify 
Petar Bojanić, Will the Judgement in the Hague Constitute a Precedent...

3. An international court should be placed on the territory where the crimes were committed because this (territory) is an ad hoc part of the international community. It is impossible to achieve the reconciliatory benefit of a war crimes trial far from the place where the crimes occurred. The institution of the condominium or "supreme authority" 39 is the only possibility for eliminating any kind of legislative competence and the status of the subject of the state whose parts committed crimes. The suspension of sovereignty -- "without 'annexing' and without intention of permanent acquisition," and without intention of temporary acquisition -- removes any kind of possibility for restrictiveness, because the essence of sovereignty is elasticity and adaptability to any kind of limitation ${ }^{40}$.

4. By the court not accepting an individual's function as a valid defence nor their belonging to a larger hierarchy which demands obedience, this court removes the obstacle to the sovereign or chief (head) of state being prosecuted under international criminal law. By judging the sovereign it is possible to reconstruct the historic relationship between crime and sovereignty. Crimes in the name of sovereignty frequently precede crimes which are on the International Tribunal's agenda, but implicate them ${ }^{41}$. However, this reconstruction initiates the suspension of international immunity (much more important than national ${ }^{42}$ ) which a sovereign enjoys as the sovereign and which is the key foundation of sovereignty as such.

the existence of the permanent members of the Security Council, who make this decision through consensus.

${ }^{39}$ See H. Kelsen, "The Legal Status of Germany According to the Declaration of Berlin", in American Journal of International Law, vol. 39, 1945, p. 522, 524-525; "Collective and Individual Responsibility for Acts of State in International Law", in The Jewish Yearbook of International Law, Jerusalem, Rubin Mass, 1949, p. 236-237.

40 E. Kaufmann, Règles générale du droit de la paix, p. 359. "L'essence de la souveraineté consiste donc dans le fait d'être sujette à des restrictions, résultant soit du fait général de la coexistence des Etats, soit des relations particulières avec des Etats déterminés, et de subir des limitations de la plénitude des pouvoirs qu'elle comprend virtuellement".

${ }^{41}$ The idea of reason of state or state secret hides the crimes which lie in the foundations of the creation of a state, preservation of state power, and protection from foreign or internal enemies. The sovereign is first of all the robber of his own sovereignty. "A people should not inquire with any practical aim in view into the origin of the supreme authority to which it is the subject, that is, a subject ought not to reason subtly for the sake of action about the origin of this authority, as a right that can be still be called into question (ius controversum) with regard to the obedience he owes it”. I. Kant, Practical Philosophy, Cambridge University Press, 1996, p. 461. Die Metaphysik der Sitten, GS, Band VI, S. 318.

${ }^{42}$ The most famous example is the refusal of the Netherlands to extradite ex-Kaiser "for a supreme offence against international morality and the sanctity of treaties". Soon after the end of World War I, in 1919, written in the Report of Commission of Responsibilities, on page 19:

"However, even if, in some countries, a Sovereign is exempt from being prosecuted in a national court of his own country the position from an international point of view is quite different". 


\section{Precedent and Sovereignty}

The meaning and power of the word "sovereignty" (today, still, the first, most important, and frequently mentioned word by governments from the exYugoslav territories ${ }^{43}$ ), one of the most problematic terms in international law and a word which has "lost any precise meaning",44, was inaugurated by President Josip Broz Tito. Almost sixty years ago, in August 1946, an incident occurred on Yugoslavian territory, today belonging to Slovenia, which is mentioned in all American military manuals dealing with intervention. The seventy-fourth US intervention, since its inception, was marked as a nuclear naval threat to Yugoslavia, which ended on August $31^{\text {st }}$ of the same year ${ }^{45}$. First, on August $9^{\text {th }}$, three Yugoslav fighter planes fired on an American transport plane and forced it to land somewhere near Ljubljana. The pilot was wounded during this incident. Ten days later, only two miles from the Austrian border, a US military plane was shot down by Yugoslav fighters north of lake Bled. All five passengers were killed. On that occasion Marshall Tito declared that the US aircraft repeatedly flew over Yugoslav territory, that they violated its sovereign territory despite his month's long frequent protests. Tito continues saying that "certain countries" strive for "an imperialistic peace", but that Yugoslavia does not want peace at any price with those "who wish to achieve their imperialistic aims at the expense of peoples who have sacrificed for the common cause all they possible could." Finally concluding his declaration with "I wish to prove who is making provocations and who wishes to deny us our rights"46. The untouchable and absolute sovereignty and territorial integrity of the Socialist Federal Republic of Yugoslavia (already in next year demonstrations were organized throughout the country because of the "Trieste case"), is the result of the great victories in World War II and civil war, the victims and sacrifices of which the president speaks, and his frequent successful maneuverings, which enabled Yugoslavia to stay independent of the Soviet

${ }^{43}$ The governments of Bosnia and Herzegovina, Montenegro, Kosovo, and Serbia are still attempting to "bridge the gap between sovereignty and self-determination." In a, November $15^{\text {th }}, 2005$, resolution by the Parliament of the Republic of Serbia concerning the terms for a political discussion on the future status of Kosovo and Metohija, the concept and term "sovereignty and territorial integrity" is mentioned four times.

${ }^{44}$ H. Kelsen, "The Legal Status of Germany According to the Declaration of Berlin", in American Journal of International Law, vol. 39, 1945, p. 522. More specifically, the crisis of sovereignty and diminishing importance of this word begins with the Peace of Versailles. "Territorial sovereignty was transformed into an empty space for socio-economic processes". C. Schmitt, The Nomos of the Earth, New York, Telos Press, 2003, p. 252 (German original S. 226).

${ }^{45}$ After a very tense situation and much insistence and pressure from America, Yugoslavia, in the end, states that it will no longer attack US planes and issues a statement of regret.

${ }^{46}$ Extracts from Chicago Tribune Press Service, August 10th, 1946 and New York Times August 21st, 1946. 
Petar Bojanić, Will the Judgement in the Hague Constitute a Precedent...

Union's influence. For the next two decades in all of the most famous international law manuals, sovereignty was defined by fantastic doctrinaire acrobatics, which have additionally injected a fictive power into this word. ${ }^{47}$ On one side, sovereignty is understood in its strictest sense, given to it by Vattel, as rule independent of any others state (any foreigner; sans dependence d'aucun etranger $^{48}$ ). In fact Yugoslavia is an absolutely closed Fichtean commercial state opposed to the imperialistic west and its peace as mentioned by Tito (the only exception is war reparations paid for Great War destruction). On the other side, because the worker and working class are truly sovereign, it was necessary to rethink and redefine this always overly bourgeoisie concept of "sovereignty". The idea of an absolutely new and open "sovereignty", or sovereignty that has yet to take place, and in which all proletarian states could eventually take part, represents a never truly discussed avant-garde theory. If there is any kind of ex-Yugoslavian philosophical legacy it is to be found here, with all of its living or deceased heirs (the assassinated prime minister being on of them). "Praxis Philosophy" was built in this contrast and this tension which existed nowhere in Europe at this time. This "condition" within the state and within its "theory of sovereignty" was only possible as long as there were problems and pressures either from the west or from the east. With the first nationalist ferment, with economic difficulties, with the unoriginal and archaic changes to the constitution, the republics de jure inherit, each one individually, an identical governing apparatus and an identical complicated ideology. All the republics, along with the two provinces within Serbia, were absolutely independent states within one state, while the communist party (and Yugoslav army) represented a common sovereign who overshadowed the others' sovereignties like a specter. All the assumption pointed to this model

\footnotetext{
47 The academic Milan Bartoš defines a state's right to independence as "the right of a state to act freely in international affairs and within its territorial borders, without unauthorized interference from other states or organizations, in these actions." (Medjunarodno javno pravo, Beograd, 1954, I, s. 272); Smilja Avramov, former advisor to Slobodan Milošević and witness in his defence at The Hague, in her book Medjunarodno javno pravo (Beograd, 1963, s. 76), writes: "Understood as going under sovereignty is the legal and factual ability of a state to undertake its functions within the state and in international affairs, independents of any and all others governments". In his 1949 text, "Načelo suvereniteta naroda u medjunarodnim odnosima i radnička klasa", from 1949 (Komunist, No. 5, s. 57), Aleš Bebler say that the institution of sovereignty has withstood the critiques of dialectical materialism and today remains the basic right of a state. Also see M. Despot's book Suverenitet u prostoru iznad državne teritorije, Beograd, 1966, s. 13-24.

${ }^{48}$ E. Vattel, Le Droit des gens, (1758), Book I, Chapter 1, paragraph 4.

${ }^{49}$ It is possible to find several subjects of sovereignty ("sovereign rights of the working people, peoples (nations) and nationalities (national minorities)") within the constitution of the SFRY. The following text, written at the brink of Yugoslavia's break up, by Slobodan Samardzić, the current advisor to the Prime Minister of the Republic of Serbia, researches the differences between the constitutional arrangements of the SFRY and other multinational federations. "Dilemma of Federalism in Yugoslavia - Problem of Sovereignty in a Multinational Federation”, in Praxis International, Vol. 11, No. 3, October, 1991, p. 377-386.
} 
Социолошки преглед, vol. XXXX (2006), no. 1, стр. 93-114

being able to last and function perfectly as a so-called well "organized hypocrisy" ${ }^{\prime 50}$. The problem was the province of Kosovo, with aspirations to become the seventh Yugoslav republic, and the Republic of Serbia, with its wish to make itself equal to the other republics, by putting an end to both provinces and establish control over all of its territory. Milošević's insistence continued for several years, and in December of 1986 he said the following:

Promene u političkom sistemu treba da omoguće SR Srbiji da ostvari status koji nema, status Republike, ravnopravan sa statusom svih drugih republika u Jugoslaviji. Srbija ne traži da bude više republika od drugih republika, ali, sigurno je, ne može dozvoliti ni da bude manje republika od drugih ${ }^{51}$.

In April 1987 he speaks in Kosovo. Here is the conclusion of that speech:

Ali, spremnost naroda i Kosova, i Srbije, i Jugoslavije, da se problemi reše i da svako da svoj doprinos, i da svi zajedno zasučemo rukave, da ih rešimo je ona garancija da ćemo rešiti i sistemske, i privredne, i političke probleme na Kosovu. (...) Jugoslavija ne postoji bez Kosova! Jugoslavija se dezintegriše bez Kosova! Jugoslavija i Srbija neće dati Kosovo! ${ }^{52}$

${ }^{50}$ This is a paraphrase of the subheading of Stephen D. Krasner book, Sovereignty, Organized Hypocrisy, Princeton University Press, 1999. The "problem of sovereignty" is treated in an interesting way in the Memorandum of the Serbian Academy of Arts and Sciences (SANU) (Dobrica Cosić, the future president of Yugoslavia, was then the president of the Academy), a document written in the fall of 1986 and published in the famous "conspiratorial" and "unfinished" version on Zagreb (the journal Naše teme, 1989, Vol. 33, No. 1-2, s. 128-163). Written in Chapter 6a, The Sovereignty of People, is: "The sovereignty of the people: At the very foundations of modern civilization is the idea that political power is vested in the people, that the sole legitimate political authority is the one which derives from the freely expressed will of the people, and that therefore there are no moral or legal grounds for any elite (by the will of God, by blood, religion, race, ideological credentials, historical merit or on any other grounds) to arrogate to itself the right to speak, decide, or use force on behalf of a nation. (...) The principle of the sovereignty of the people has been affirmed by the democratic political philosophy and practice of the democratic revol' utions of the 18th century. However, socialist theory has taken this principle to extremely radical lengths. If a monopoly of economic power is also one of the means by which elites are formed, which can foist themselves upon society and gain full control over its political life, than all the institutions which make such a monopoly of power are incompatible with the principle of the sovereignty of the people, regardless of whether it is big capital or a bureaucratic state. In this sense, full sovereignty of the people could be achieved only in a classless society, in which political, economic, and cultural life would be organized in a democratic manner" (s. 145).

${ }^{51}$ S. Milošević, Godine Raspleta, Beograd, BIGZ, 1989, s. 121.

${ }^{52}$ Ibid, s. 145-146.

"Because of this, even today, when speaking of the province of Kosovo and Metohija, we expect, with full confidence, that the Security Council, with the force of its authority, will ensure that even in the case of Serbia and Montenegro the indestructible principles of respect for sovereignty and territorial integrity will not be ignored. I am convinced that it is our common belief that the fragmentation of a confirmed democratic state is unthinkable, and that, against its 
Petar Bojanić, Will the Judgement in the Hague Constitute a Precedent...

In October of 1988 , at the $17^{\text {th }}$ Congress of the League of Communists of Yugoslavia, Milošević addressed his comrades, communists from the other republics who had for several years refused to support him in changing the status of Serbia:

Medjutim, u nastojanju da sačuvaju svoje pozicije oni pokušavaju da blokiraju promene Ustava. C̆ak, i to smo videli, izvlačenjem na svetlost dana iz duhovnog naftalina, upozorenje o opasnosti koja se svima sprema od "Velike Srbije". Odmah da vam kažem drugovi, Srbija, kao što je poznato, nema pretenzija na teritorije drugih republika, ali ima pretenzija na teritoriju svoje Republike. Da li je ta teritorija velika ili mala, zavisi od aršina kojim se meri, ali tolika kolika je ona mora da ostane i takva će i da ostane. I u tome Srbija očekuje podršku svih republika, kao što je sama spremna da takvu podršku drugima da, što je uostalom u sličnim situacijama, kad su druge republike bile u pitanju, uvek činila ${ }^{53}$.

This last fragment is an excellent example of an introduction to a sovereign act as "pretension" (this is the world used by the president) to "have" that which already belongs to you and is already yours. The idiom "I want only what is mine" is complimentary to the idiom "leave me alone," and the true shape of so-called "negative sovereignty" ${ }^{, 4}$. First, the president requests something of the others in order to violate the constitution, pass a new constitution, and in a certain way make a precedent which only concerns him. It seems that he is not capable of doing this himself or of giving up, if this support is not given. So that he doesn't have to give up, he uses the "restriction of the sovereign" ("I don't want the others, I want mine"), the "restriction of the threat" ("I could take the others") and the "restriction of the just" ("but I want only mine"). The threat is perfectly accomplished and strengthened by the sentence in which the president mentions a "Greater Serbia"

will, its intentionally recognized borders be changed." Speech by the Prime Minister of the Government of the Republic of Serbia, V. Koštunica, at a Security Council meeting about Kosovo and Metohija, October $24^{\text {th }}, 2005$.

${ }^{53}$ Ibid, s. 269.

${ }^{54}$ The distinction between positive and negative sovereignty began as a retort to Isaiah Berlin's distinction between positive and negative liberty. See P. Kahn, Chapter I. 'Positive and Negative Sovereignty in International Law', "The Question of Sovereignty", in Stanford Journal of International Law, Summer 2004, Vol. 40, No. 2, p. 260-265. This sort of distinction belongs to the old attempts at redefining and saving the concept of sovereignty (and to perhaps again think the abandonment of sovereignty or the myth of its abandonment). One of the most famous distinctions refers to the difference between legal and effective sovereignty. This difference could possibly be found in the distinction made by Robert Jackson between states and quasistates, where the "quasi" refers to the percent based on which one state is a state or is still not a state. In this sense all states are de jure sovereign, but are not de facto or perhaps only so in a certain measure. This means that states differ absolutely in the amount of sovereign power they can use, and this foremost depends on the strength of its institutions. Therefore, states have completely different capacities and competence to participate in the international and transgovernmental regimes, to control the territory over this they have sovereignty, to exercise the domestic dimensions of legal sovereignty, to govern domestic affairs and control borders etc. 
(in the speech itself the word is found in quotation marks). It is not "Greater Serbia" that is in spiritual naphthalene but the "warning of the danger" of Serbia, which is supposed to expand. The president mentions the Turkish word "arshin" (an imperial measure ${ }^{55}$ ) and plays with the attributes of greater and smaller which pertain to the present-future territory. Serbia is real, as big as it is, says the president, and it will stay that way. Naphthalene is a poisonous and flammable chemical used for protection against pests and cleaning. Bringing something out of naphthalene means that something was set aside, carefully removed, and saved for another time, but also that it was saved and that it exists as such. That what is being brought out of naphthalene are the warnings and fears of the proletariat comrades who block the pretensions of the sovereign. Both the naphthalene and spirit (the spirit which is flammable, which is both a poison (pharmakon) and remedy, because it protects and preserves this "warning of the danger") are in the others possession. This is very important, and is in no way a mistake or clumsiness in the sovereign's use of words and threats ${ }^{56}$.

The support of all the comrades was de facto and de iure received a short time later, but only after Milošević alone suspended the old constitution and in so doing terminated the autonomous provinces. In a series of declarations concerning sovereignty and referendums, all the ex-Yugoslav republics followed Milošević's sovereign act. From that moment, the right to sovereignty and self-determination was defended by aggression and crime.

${ }^{55}$ Arshin (metric unit) measures 61 centimetres, but in the hands of the Turkish Emperor, who ruled Serbia for centuries, arshin is a measure which changes based on the one who is doing the measuring.

${ }^{56}$ Complementary to the fear of a Greater Serbia is the fear of a Greater Albania. In the text "Tragedy of National Conflicts in 'Real Socialism'. The case of the Yugoslav Autonomous Province of Kosovo" (Praxis International, Vol. 9, No. 4, p. 423) M. Marković, the future head of Milosevic's Socialist Party writes: "Albanians would have to be prudent enough to renounce the impossible program of creating a Great Albania from the parts of existing Balkan states. Each of those states - Yugoslavia, Turkey, Bulgaria, Rumania, Hungary - have millions of Albanians as minorities living in their countries. Albanians would have to settle to that. And rather than jeopardizing their autonomy in Kosovo by abusing it, they should make best use of their rights and liberties and materials aid that would be available in Yugoslavia and Serbia". 
Petar Bojanić, Will the Judgement in the Hague Constitute a Precedent...

Петар Бојанић

A п стракт

Институт за филозофију

и друштвену теорију

Београд

\section{ДА ЛИ ЋЕ ПРЕСУДА ХАШКОГ СУДА УСТАНОВИТИ ПРЕСЕДАН У МЕБУНАРОДНОМ ПРАВУ?}

О великом злочину (mala in se; scelus infandum) и суверенитету

У тексту, чији наслов представља парафразу наслова познатог Келсеновог текста из 1947 године ("Will the judgment in the Nuremberg trial constitute a precedent in international law”), истражујем однос злочина (ратних злочина, злочина против мира, човечности; појединачне или колективне одговорности, казне, итд.) и суверенитета нових држава бивше Југославије. Путем компаративне анализе неколико основних појмова и институција међународног права који утемељују функционисање Нирнбершког и Хашког суда, намера ми је да испитујем могућност установљења преседана у Келсеновом смислу. Дакле, да ли је могуће да Хашки суд произведе правну одлуку или правну пресуду која би у будућности могла да послужи у сличним случајевима?

Кључне речи: преседан, међународно право, одговорност, суверенитет, пресуда. 